\title{
Impact of Branding on Impulse Buying Behavior: Evidence from FMCG's Sector Pakistan
}

\author{
Mudassir Husnain $^{1} \&$ M Waheed Akhtar ${ }^{1}$ \\ ${ }^{1}$ International Islamic University, Islamabad, Pakistan \\ Correspondence: Mudassir Husnain, MS Student, International Islamic University, Islamabad, Pakistan.
}

Received: October 20, 2015

Accepted: November 3, 2015

Online Published: January 18, 2016

doi:10.5430/ijba.v7n1p59

URL: http://dx.doi.org/10.5430/ijba.v7n1p59

\begin{abstract}
The purpose of this study is to provide an insight into the impact of branding on impulse buying behavior in FMCG'S sector Pakistan and to examine whether branding has sufficient influence on impulse buying behavior. As branding for packaged products is on rise in competitive markets and significance of packaging considered as a vehicle for communication. A questionnaire derived from the previous studies and relevant literature was completed by 180 university students who often engage in impulse buying. Survey examine how packaging elements can affect impulse buying behavior and to understand consumer behavior toward such products. Convenience sampling technique was used. Multiple regression analysis assessed the impact of branding on impulse buying behavior. Result indicates that branding has a significant impact and predict good proportion of variance in impulse buying behavior. It is reasonable to conclude, on this evidence, that impulse buying behavior can be reinforced and retained by marketers through branding, nice packaging and labeling in a sophisticated manner. The relationship investigated in this study deserves further research because the data collected is from one sector in one country, more studies required before general conclusion can be drawn.
\end{abstract}

Keywords: packaging, labeling, impulse buying, FMCG, Pakistan

\section{Introduction}

The act of shopping is main feature of consumer's lives; it is continually growing and making applicable inquiry and understanding of this field. Impulse buying has been considered as an important form of consumer buying action (Cobb \& Hoyer, 1986). The factors triggering such purchases are important to understand, as nine out of ten shoppers buy on impulse occasionally (e.g. Silvera et al., 2008; Cobb \& Hoyer, 1986). Today almost $70 \%$ of buying choices are made at outlets or selling points (Heilman et al, 2002), which report for huge quantity of products sell under a wide series of product categories by impulse buying (Weinberg \& Gottawald, 1982). So what is an impulse buying exactly? (Stern, 1962) describes that planned buying behavior is based on rational decision making and is more time consuming. In contrast, unplanned buying includes purchases without such pre planning and rational decision making therefore includes impulse buying. Scholars suggested that most important factors that separate planned and impulse buying is speed with which buying decisions done. (Piron, 1991) defines an impulse buying that comprises four criteria. (Hodge, 2004) impulse buying is unplanned, arise from reaction to stimulus, involves cognitive and emotional reaction, and "on spot decided". Furthermore, impulse buying viewed as "a response to inexpensive offerings" by previous research (Hausman, 2000), existing literature considered the phenomenon as an individual characteristics or trait. (Rook, 1987) considered impulsive behavior is a "lifestyle trait" of consumers. Some researches expose that consumer experience strong feelings about impulse purchases than about planned buying (Gardner \& Rook, 1988).

In last decades, shopping experience has been studied by the researches both in hedonic and utilitarian perspectives. Utilitarian behavior of consumer can be defined as rational approach involving a purchase that is made efficiently, still if the shopping may not give any fun (Babin et al, 1994). In that case, shopping experience can be viewed by consumers as an achievement of planned goal. In contrast, (Gardner \& Levy, 1955; Levy, 1959; Tauber, 1972), (Hirschman \& Holbrook, 1982) develops theory of Hedonic value that engages emotive and multi-sensory sides of consumer's experiences with brands.

Packaging is considered as key marketing tool used by marketers. Good package can create promotional values and convenience (Kotler, 2004). It provides a number of purposes, as shielding the product and protects once obtained, 
serving to get recognition of brand, helps and convince customers to purchase the particular brand. Primarily, wrapping or packaging was proposed mainly to give safety. Due to its growing importance, it becomes a key feature in gaining customers. (Pandey, 2005) argues that buying on impulse is growing quickly. Package is extremely valuable tool for motivating impulse buying (Sehrawet, 2002; Sehrawet \& Kundu, 2003).

(Kacen \& Lee, 2002) propose that there are several features of a country's culture that interact with shoppers' impulsiveness. So it is important for us to investigate the impact of branding on impulse buying in actual conditions from different cultural perspective like Pakistan.

Our research provides valuable insights for Pakistani marketers in various ways. In order to encourage impulse buying behavior, marketing managers may give emphasis to fun, playfulness, excitement and diversity in their promotional activities. They may portray individuals who like fun and excitement, and who, at the same time, cannot oppose buying colorful packaged brands whenever they see them. Additionally, to remove the negative assessment and convert the impulse buying intention into behavior, marketers might show that impulse buying encourage customer self esteem, and others recognize impulse purchasers as modern and innovative. At last, eye-catching package and labeling promote consumers' impulse buying motivation and behavior.

This paper is going to explore how marketers in FMCG'S sector in Pakistan can urge impulse buying behavior through branding, as a competitive weapon to gain more sales performance. Fast Moving consumer Goods (FMCG) are normally those products having quick turnover and fairly low cost. They get changed in a year or less and the purchase cycle is comparatively little as contrast to other brands. Milk pack, beverages, toothpaste, tea, bakery items are just a few areas where FMCG's have made great success in Pakistan.

The objective of this paper is to explore customer's characteristics about impulse buying behavior and to investigate relationship among key dimensions of impulse buying (utilitarian and hedonic shopping value) and branding in FMCG'S sector Pakistan. Furthermore, to investigate the antecedents of consumer's impulse buying behavior based on this literature and model, specifically through branding perspective. We suggested that in context of impulse buying, consumer intentions will not play vital role in predicting buying behavior. But we want to check out that the consumer enthusiasm, esteem, and packaging and labeling of brand significantly influence on impulse buying behavior among Pakistani customers.

Therefore the broad objectives for our study are:

- To examine consumers' motivations for making impulse buying of FMCG in Pakistan.

- To identify the main aspects that explained the shopping motivations among Pakistani consumers.

- To propose different approaches regarding to packaging and labeling for practitioners and retailers in Pakistan, so that they can devise strategies, to achieve their marketing objectives and goals.

\section{Literature Review}

Early efforts to study impulse buying behavior especially prior to 1980 's seem to be conflicting as they much emphasizes on to classify impulse buying behavior's other dimensions, rather than to understand phenomena what in fact impulse buying behavior is? And why consumers are addicted to this type of behavior so frequently. For that reason previous study focuses on low involvement product in small number. After that study in this area reveals that it is personal characteristics irrespective of response to inexpensive product offering. Generally found from previous studies that this behavior tend to satisfy emotional/hedonic desires for enjoyment, social associations, and pleasure (Haussmann, 2000; piron, 1991). This means that impulse buying behavior can be promoted through emotional and social factors.

\subsection{What Is Impulse Buying?}

Impulse buying behavior is sudden, compelling, not preplanned, hedonically multifaceted behavior in which rapidity of an impulse decision process precludes thoughtful and purposeful consideration of alternative information and choices (Bailey \& Nancarrow, 1998).

Early research focus on what products promote impulse buying and in which environment of retail. But this body of research fails to show the motivations leading impulse buying behavior. Now improvements start to determine "when" and "why" impulse buying occurs (Verplankin \& Herbadai, 2007). According to "THE ECONOMIST" (2000) approximately one fourth of Amazon.com's sales made by promoting impulse purchases through recommending and suggesting other products of category too. Impulse buyers are less likely to care about the result of impulse buying (Rook, 1987) and tend to not focus on reviewing the decision process as done by the planned shoppers (Jones et al., 2003). According to (Hassay \& Smith, 1996) impulse buying behavior has four types: 
1) Intended or planned impulse buying.

2) Reminded impulse buying.

3) Pure impulse buying.

4) Fashion oriented impulse buying.

This implies that impulse buyers tend to satisfy their particular needs (social, emotional) irrespective of consequences of impulse buying like embarrassment. To find out the causes of impulse buying research can be divided into two areas.

\subsection{Utilitarian and Hedonic Perspective of Shopping}

Valuable work done on the shopping experience is done in the last decade. Utilitarian consumer behavior can be described as "The rational approach and objective evaluation with focus on efficiency in purchase, even this experience may not provide fun and playfulness" (Babin et al., 1994). According to this consumer considered shopping experience as task oriented. However this utilitarian aspect is not enough to cover full consumer behavior. In 1950's researcher introduced hedonic concept of shopping experience that involve emotions of consumer with product. Researcher highlights the worth of enjoyment and emotions (Arnold \& Reynolds, 2003; Babin et al., 1994; Wakefeild \& baker, 1998). Hedonic consumption is fun oriented for fun, fantasy, and playfulness (eg.Vacationing in Islamabad) (Hirschman \& Holbrook, 1982).

On the other hand utilitarian is more objective, task oriented urged by desire of fundamental needs (eg. Consumption of bath soap for washing hands). Necessary consumption in utilitarian aspects is valued by consumers strongly. Similarly frivolous consumption of hedonic aspect is strongly valued by consumers.

\subsection{External and Internal Causes of Impulse Buying}

External and internal factors of impulse buying cause consumer behavior in both conditions (Wansink, 1994). Some cues triggers that urge consumers to urge on buy impulse (Rook \& Fisher, 1995). Manipulation of certain external stimuli can increase the chance of impulse buying (Thomas \& Forsythe, 1991). This implies that there are some external factors that promote impulse buying. Also there are some individual or interpersonal characteristics that promote impulse buying behavior.

\subsubsection{External Causes of Impulse Buying}

These external factors of impulse buying refer to those cues that marketers manipulate to engage customers in impulse buying behavior (Youn \& Faber, 2000), usually when customer faces some promotional incentives (Dholakia, 2000; Rook, 1987). These efforts of marketers not only attracts new customers but also useful to keep existing customers by recommending and suggesting other offering in product category through up selling and cross selling. These promotions may include free shipping, gift, buy one get one free and like.

\subsubsection{Internal Causes of Impulse Buying}

Internal cues of impulse buying relates to individual characteristics like personality traits, emotional states and other demographic factors (Kacen \& Lee, 2002). It includes consumer affective and cognitive states (Youn, 2000). Impulsive or non-impulsive consumer behavior is determined through consumer affection and cognition processing in internal stimuli. And when consumer faces this "powerful urge to buy immediately" he/she make impulse buying.

Cognition refers to how one understands and analyze information and it leads towards impulse buying behavior with little cognitive deliberation, disregard to consequences (Youn, 2000). The more the consumer is in affective state and less in cognitive then there is more chances to engage in impulse buying behavior (Dholakia, 2000; Rook, 1987; Youn \& Faber, 2000).

\subsection{Normative Evaluation of Impulse Buying}

These are the consumer judgments about whether to buy or not in a specific situation (Rook \& Fisher, 1995, p.306). This may arise negative views about impulse buying behavior as "Risky and Useless" (Rook \& Fisher, 1995). After shopping on impulse consumer might feel guilt, embarrassment as it was unnecessarily to spend money (Dittmar \& Drury, 2000). Yet, this is not considered as waste of money, time by many of consumers (Rook, 1987; Haussman, 2000).

This implies that when consumers feel it reasonable or appropriate they engage in impulse buying behavior. 


\subsection{Branding}

Brand is any name, sign, symbol, color term that differentiate the product of one seller to another. Word brand comes from the word "brander" means "to burn". It is valuable asset of a firm that enhanced brand strategies build positioning and equity (Keller, 1998). Most of the brands chosen by consumers for purchase are based on impulse buying. Brand name on packaging increase customer response, purchase preference in impulse. Unique brand names play a critical role in all business sectors. From Nestle to Caterpillar sales can be effected when firms has not unique brand name although product quality and service are_in there.

\subsection{Packaging and Labeling}

According to recent studies point of purchase and advertisements institute (POPAI) shows that 70 percent of purchases comes from point of purchase. Packaging has impact in marketing decision because it provides information about product and contains it safely. Consumer appreciates the information added in marketing message (Chandlers, 1977) reports that information containing humor will remain in mind of customer for the purchase. Packaging is one of the important factors in purchasing in a sale point (Prendergast \& Pit, 1996). With increasing trend of self service packaging put itself as "salesman" at the shelf and is a source of communication and branding (Rettie \& Brewer, 2000). Package must insure consumer response to good.

Now people have no time they are more addicted to impulse buying. So package has to promote, glamorize and improve the worth of contents (Stern, 1962). Now consumers are more educated and pending their decision at point of purchase, this leads them to buy on impulse. Packaging has to give additional information itself and stimulus because of self service (Tauber, 1972). Packaging provides view of better looking and is beneficial for both of low and high involvement products as a means of comparing with others products and provides guideline how to use. So customer becomes satisfied. Research shows packaging is a costly too. It must position or differentiate from others in term of sign, logo, trademark, symbol, color, shape, and additional features. Packaging significantly influence on the buying decision process. In some cases labeling on package considered more consciously by customers.

Packaging has dual functions as a logistics and as marketing. Logistics only protect product from damages, but in marketing it becomes mean to communicate message about attributes. If it convey message effectively, consumer expect it as good quality product, if it fail to do so consumer expect it as a low quality and not tend to purchase. There are some package elements that effect purchase decision of consumer (Visual and Informational). Visuals contain graphics, shape, size, and lies in affective or subjective decision making. Informational elements contain information given by technologies and lies in cognitive or objective decision making. For low risk and low involvement products buyers do not strive for information.

On the basis of literature review discussed above. We therefore propose that:

H1: Branding has significant and positive effect on impulse buying behavior.

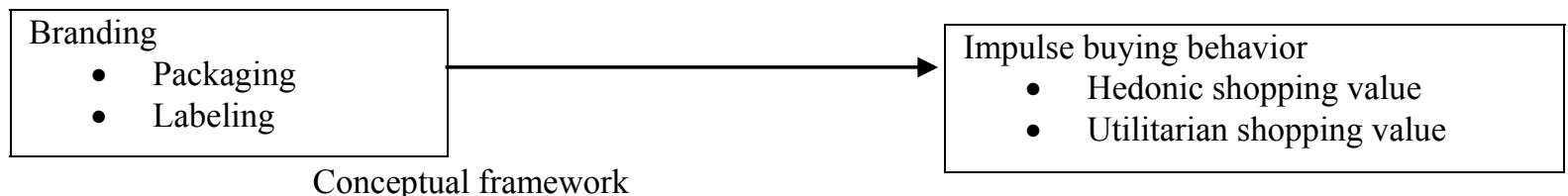

Conceptual framework

\section{Research Methodology}

\subsection{Population and Sample Profile}

University students were the population of this study in the city of Islamabad, capital of Pakistan which is recognized as dense and ethnically diverse city (peoples with different background from all over the country are living there). We can't argue that the students in this city completely represent the Pakistani sample, but we can draw up a general picture of how branding impacts on impulse buying behavior in FMCG'S sector Pakistan. Sampling technique that was used to select respondents was convenience sampling.

Respondents filled up a survey questionnaire during the period of March-April 2012. Responses were analyzed from almost 200 student customers who often engage in shopping, 185 questionnaires were returned back, among them 181 were useful and response rate was $90 \%$. A survey was used to investigate the relationship. The constructs in questionnaire presented information regarding utilitarian shopping value, Hedonic shopping value, packaging, and 
labeling. And, the main aim of the questionnaire was to know that how respondents think about excitement, fun, playfulness, and packaging and labeling on a brand whenever they shop.

\subsection{Variables of Study}

Items that determine the construct dimensions in questionnaire were adapted from past researches. We plan to adopt a useful and practical scale, to ensure parsimony and applied simply.

In our study we used a questionnaire composed of dimensions: one from (Arnold \&Reynolds, 2003) with eight hedonic shopping value items (eg. I go shopping when I want to treat myself to something special) the fun scale introduced by (Farber \& O'Guinn, 1988) is incorporated with hedonic consumption scale; whereas it is initially created by (Unger, 1981), and another from (Kim, 2006) with utilitarian shopping value items (e.g. It feels good to know that my shopping trip was successful). Packaging and labeling from (Silayoi \& Speece, 2004) for example, (Nice package design can influence my decision as it sometimes reflects good quality products) and (Nutrition facts on the package are very important for me to judge the product quality and purchase that product).

All scales resulted in a set of 22 items that are measured on a five-point Likert-type scale. Statistical Package for Social Sciences was used to analyze the data. Responses of all items were measured by agreement with statements, which are ranging from $1=$ strongly agree to $5=$ strongly disagree on a five-point Lakers scale.

\section{Result Analysis}

\subsection{Demographics of Respondents}

The survey also included demographic information questions of respondents (such as gender, age, marital status, and income). Demographic data shows that majority of respondents were male: 200, to 12 percent female. Just more than three quarters (79\%) were below $40.43 \%$ were graduates. 64 percent among the respondents are unmarried.

Different statistical tools used to analyze data; correlation and multiple regression analysis were carried out to examine the association among the dimensions of branding and impulse buying behavior, in this perspective. We carefully incorporate items for our survey, are from the researches of different authors, and the results are seem to be consistent with western context (Beharrell \& Denison, 1995), less work done in Asia, and we want to check it out from Asian perspective, like Pakistan.

According to Lee et al. (1999) if model that we are going estimate is not well defined or miss specified, it considered as biased and not consistent. For the sake of this we assess our model using Ramsay's Reset test, the p value of Ramsay's test indicates our model for utilitarian and hedonic shopping value is 0.053 and 0.422 respectively which are greater then 0.05 , so we can argue that there is no specification fault in this model. So, this model is best to find out the impact of branding on impulse buying behavior. The $\mathrm{p}$ value for hetroskedecity is greater than 0.05 so there is no chances of hetroskedecity in our data.

We include gender as a dummy variable in our research and is influencing decision process based on impulse buying (Chiger, 2001: Marks, 2002: Otnes \& McGrath, 2001).As packaging and labeling increases then impulse buying also increases but on the basis of gender the relationship of packaging and labeling, and impulse buying is more significant for male $(\mathrm{p}=0.013014)$ than female $(\mathrm{p}=0.442662)$, that are consistent with findings of (Otnes \& McGrath, 2001).

\subsection{Correlation Analysis}

Table 1. Means, slandered deviation, correlations, reliabilities

\begin{tabular}{llccll}
\hline & Mean & SD & HSV & USV & PL \\
\hline HSV & 2.4 & .705 & $(.693)$ & & \\
\hline USV & 2.40 & .749 & $.696^{* *}$ & $(.821)$ & \\
\hline PL & 2.60 & .70 & $.698^{* *}$ & $.651^{* *}$ & $(.841)$ \\
\hline
\end{tabular}

**. Correlation is significant at the 0.01 level (2-tailed). $\mathrm{N}=180, \alpha$ values in parentheses

We computed means and standard deviations for each variable and created a correlation matrix of all variables used in hypothesis testing. Means, Standard deviations, reliabilities, and correlations among all scales used in the analyses are shown in Table 1 . The constructs of the entire variables were tested for reliability analysis using cronbach alpha 
scores, and the values of cronbach alpha for all the variables were above the minimum level of 0.70 which was recommended by (Nunnally, 1978) and same found in the study of (Rook \& Fisher, 1995). After analyzing the Table 1 , we can see that the relations between HSV and PL, and PL and USV are significant at the 0.01 level. And we also conclude that the correlation values between all the independent variables are less than 0.80 , so the chances of multicolinearity are nothing. This is satisfactory for our research intentions as well as match up positively with value calculated by (Goldsmith et al., 1999).

\subsection{Regression Analysis}

Table 2. Regression analysis

\begin{tabular}{|c|c|c|c|c|c|c|}
\hline \multirow[b]{2}{*}{ Model } & & \multicolumn{2}{|c|}{ Unstandardized Coefficients } & \multirow{2}{*}{$\begin{array}{c}\text { Standardized } \\
\text { Coefficients } \\
\text { Beta } \\
\end{array}$} & \multirow[b]{2}{*}{$\mathrm{t}$} & \multirow[b]{2}{*}{ Sig. } \\
\hline & & $\mathrm{B}$ & Std. Error & & & \\
\hline \multirow[t]{2}{*}{1} & (Constant) & .644 & .146 & & 4.416 & .000 \\
\hline & PL & .702 & .054 & .698 & 12.987 & .000 \\
\hline
\end{tabular}

a. Dependent Variable: HSV

Table 2 shows the regression analysis between Packaging and Labeling as independent variable and Hedonic Shopping Value as a dependent variable.

The result depicts that the relationship between Packaging and Labeling and Hedonic Shopping Value is positive and significant $(\beta=0.698, \rho<0.05)$. The $\beta$ value of $\mathrm{H} 1$ shows that if one degree increases in Packaging and Labeling then Hedonic Shopping Value will be increased by 69.8 percent. The $\rho$ value is less than 0.05 so H1 is accepted. Our findings provide the same results as with previous studies of (Kacen \& Lee, 2002).

Table 3. Regression analysis

\begin{tabular}{|c|c|c|c|c|c|c|}
\hline \multirow[b]{2}{*}{ Model } & & \multicolumn{2}{|c|}{ Unstandardized Coefficients } & \multirow{2}{*}{$\begin{array}{c}\text { Standardized } \\
\text { Coefficients }\end{array}$} & \multirow[b]{2}{*}{$\mathrm{t}$} & \multirow[b]{2}{*}{ Sig. } \\
\hline & & $\mathrm{B}$ & Std. Error & & & \\
\hline \multirow[t]{2}{*}{1} & (Constant) & .594 & .164 & & 3.617 & .000 \\
\hline & PL & .697 & .061 & .651 & 11.434 & .000 \\
\hline
\end{tabular}

a. Dependent Variable: USV

Table 3 shows the regression analysis between Packaging and Labeling as independent variable and Utilitarian Shopping Value as a dependent variable.

The result indicates that the relationship between Packaging and Labeling and Utilitarian Shopping Value is positive and significant $(\beta=0.651, \rho<0.05)$. The $\beta$ value of $\mathrm{H} 2$ shows that if one degree increases in Packaging and Labeling then Utilitarian Shopping Value will be increased by 65.1 percent. The $\rho$ value is less than 0.05 so H2 is accepted. Our findings confirm the findings of (Hassay \& Smith, 1996).

\section{Discussion and Conclusion}

Obviously, packaging is central tool of marketing and it is also understood that poor package can push consumers away from purchasing the product. Results of this study support the proposition shown earlier. Generally saying, choice of the product is greatly influenced by visual elements of the package, and labeling has the key influence on Pakistani consumers and results favorably relates with past studies conducted in Asian context (Silayoi \& Speece, 2004).

Nice-looking packaging can break the competitive clutter by generating consumer attention. Though, informational words on labeling are becoming more and more vital and influence choice in fast moving consumer goods. Customers can judge FMCG'S quality by seeing label if they were taking into account products more carefully (Peck 
\& Wiggins, 2006). But, not all the essentials of packaging are same as with how Western customers react to packaging while doing shopping on impulse, so marketers in Asia have to adapt packaging in most effective ways. This seems to be same as (Walle's, 1997) point of view that broad spending patterns may be alike, but not specifically. In psychology, the vast area of cross-cultural research summarized in (Nisbett, 2003) point out that thinking patterns of Asians are right brain-oriented, which create distinctions in how they buy products base on packaging and branding.

Graphics shape/size and visual elements positively influence choice more in low involvement conditions (FMCG); therefore, customers tend more towards impulse buying. Again, marketers must communicate and promote their product effectively through packaging. On the basis of results, several valuable implications can be drawn. First, in reality, most of the consumers engaged in impulse buying in their daily life and it is almost universal. For example, most people buy products without any planning because they feel the need to buy product when seeing it on sale. The present study is helpful for marketers using packaging as a valuable branding tool to carry out their marketing objectives. In addition, this paper also supports that people who do impulse buying either have more emotional motivation and more hedonic goals or have more rational motivation having utilitarian goals.

Furthermore, marketers should classify whether the product positioning is hedonic or utilitarian in market. On the basis of findings of (Rook \& Fisher, 1995), this research suggests that consumers not always consider impulse buying negatively, but viewed time consuming search behaviors as an alternative. Thus, marketers can use strategy in which they can appeal utilitarian benefits to monetary-based promotions and hedonic benefits to nonmonetary-based promotion, and on that bases they can choose further right promotion tools.

Consumers purchase brands for a number of motives like, social, emotional gratification, fun, playfulness or fantasy. As some respondents in earlier studies suggest, impulse buying feels little bit like doing somewhat naughty, but innocent (Rook, 1987).

\subsection{Management and Consumer Implications}

This study gives valuable insights to marketers working in different FMCG companies in Pakistan, retailers and academicians to understanding relationships among, packaging and labeling and impulse buying behavior. The managerial suggestions of this examination might as well be honestly evident. The research propose a few managerial suggestion for advertisers, if retailers want to enhance and encourage impulse buying, they have to develop setting where customers shop irrespective of negative feelings of impulse. Retailers can stress rationality purchasing as well as non economic rewards in their promotion efforts. Moreover, Pakistani retailers have to make store environment more sophisticated, make strategies such as stocking more stock, animating environment and atmospherics, and expanding information might be helpful to encourage impulse buying. Retailers can motivate, through favorable profit approaches, through relaxation in return policies or increase in store hours (Rook \& Fisher, 1995).

For consumers, if impulse is a consequence of information overloaded, they may decrease the information processing demands by limiting search to a small number of products or to a number of characteristics of large number of products. To moderate moods, consumers can also choose other methods rather than moving to impulse buying. Furthermore, they should anticipate retailers' tactics who control their frame of mind to manipulate their buying decision processes.

For managers and executives: It is manager's job to make shopping as a fun. We "studied" impulse buying as inefficient and wasteful act. Why? We undergo buying process in our daily life and sometime purchase on a moment. But this doesn't indicate that such behaviors are not good. Hausman's research shows that, being thoughtless is far from impulse buying, they are the result of longer buying decision process. For example, if we decide to purchase a dress, might be main consideration ('I want dress for my cousin wedding') but if that particular decision made 'on impulse' (I saw dress and bought it because it looked right and fitted).

In addition, managers should acquire the right employees and coach them as well. Employee's service and observational skills should be focused in training. Marketers should focus their store layouts in order to appeal impulse buyer, so that they initiate unplanned purchases (Hawkins et al., 1995).

\subsection{Limitations and Suggestions for Future Research}

As stated earlier, this study is conducted in the city of Islamabad, capital of Pakistan which is recognized as dense and ethnically diverse city (peoples with different background from all over the country are living there). So, several limitations were found in our study that put question mark. First, research participants were university student in one city, so do not characterize a diverse population that represents whole population. More appropriate samples are 
desired that comprise more geographic areas, cross-national comparisons and with more diverse representation of global shoppers. Second, findings are limited to FMCG'S shopping perspective. There are many drives that direct to buying on impulse (Hausman, 2000). Future research can advance these efforts to offer further insight into multifaceted sociopsychological procedure containing these behaviors by adding numerous variables, like variety seeking and attitudes towards impulse buying, impulse resistance strategies (Dholakia, 2000). Additionally, more situational variables like time availability and money (Beatty \& Eerrell, 1998) with different product category level distinctiveness possibly will effects impulse buying (Jones, Reynolds, Weun, \& Beatty, 2003) and novelty seeking (Van Trijp, Hoyer, \& Inman, 1996). Third, other consumer products or different product category should be including in future researches in order to further expand the findings of the study like accessories, apparel, home furnishings, cosmetics etc. Another exciting area for future studies would be to examine the interaction between culture and impulse buying in different conditions. Future studies may apply further improvements in group dynamics to assess individual impulse buying (Forsyth, 2000; Shaw, 1981).

\section{References}

Arnold, M., \& Reynolds, K. (2003). Hedonic shopping motivations. Journal of Retailing, 79(2), 77-95. http://dx.doi.org/10.1016/S0022-4359(03)00007-1

Babin, B., \& Darden, W. (1994). Exploring the concept of affective quality: Expanding the concept of retail personality. Journal of Business Research, 29(2), 101-109. http://dx.doi.org/10.1016/0148-2963(94)90014-0

Babin, Barry, J., Darden, William R., \& Griffin, Mitch. Work and/or Fun: Measuring Hedonic and Utilitarian Shopping Value. Journal of Consumer Research, 20, 644-656. http://dx.doi.org/10.1086/209376

Bayley, G., \& Nancarrow, C. (1998). Impulse purchasing: A qualitative exploration of the phenomenon. Qualitative Market Research: An International Journal, 1(2), 99-114. http://dx.doi.org/10.1108/13522759810214271

Beatty, S. E., \& Ferrell, E. M. (1998). Impulse buying: Modeling its precursors. Journal of Retailing, 74(2), 169-191. http://dx.doi.org/10.1016/S0022-4359(99)80092-X

Beharrell, B., \& Denison, T. (1995). Involvement in a routine food shopping context. British Food Journal, 97(4), 24-9. http://dx.doi.org/10.1108/00070709510085648

Chandler, A. (1977). The Visible Hand: The Managerial Revolution in American Buisiness. Cambridge M.A Belknapp Press.

Chiger, S. (2001). Consumer shopping survey. Catalogue age, 18(9), 57-60.

Cobb, C. J., \& Hoyer, W. D. (1986). Planned versus impulse purchase behavior. Journal of Retailing, 62(4), 384-409.

Dholakia, U. (2000). Temptation and resistance: an integrated model of consumption impulse formation and $\begin{array}{lllll}\text { enactment. Psychology and } & \text { 955-82. }\end{array}$ http://dx.doi.org/10.1002/1520-6793(200011)17:11<955::AID-MAR3>3.0.CO;2-J

Dittmar, H., \& Drury, J. (2000). Self-image - Is it in the bag? Journal of Economic Psychology, 21, 106-145.

Farber, R. J., \& O'Guinn, T. C. (1988). Compulsive consumption and credit abuse. Journal of Consumer Policy, 97-109. http://dx.doi.org/10.1007/BF00411522

Forsyth, D. (2000). One hundred years of group's research: Introduction to the special issue. Group Dynamics: Theory, Research, and Practice, 4, 3-6. http://dx.doi.org/10.1037/1089-2699.4.1.3

Gardner, B., \& Levy, S. J. (1955). The product and the brand. Harvard Business Review, 33, 33-9.

Gardner, M. P., \& Rook, D, W. (1988). Effects of impulse purchases on consumers' affective states. Advances in Consumer Research, 15, 127-30.

Goldsmith, R. E., Moore, M. A., \& Beaudoin, P. (1999). Fashion innovativeness and self-concept: a replication. Journal of Product \& Brand Management, 8(1), 7-18. http://dx.doi.org/10.1108/10610429910257904

Hassay, D. N., \& Smith, M. C. (1996). Fauna, foraging and shopping motives. Advances in Consumer Research, 2, $510-15$.

Haussman, A. (2000). A multi-method investigation of consumer motivations in impulse buying behavior. Journal of Consumer Marketing, 17(5), 403-426. http://dx.doi.org/10.1108/07363760010341045 
Hawkins, B., \& Coney. (1995). Consumer Behaviour, Implications for Marketing Strategy. Irwin Inc., Homewood, IL.

Heilman, C. M., Nakamoto, K., \& Rao, A. G. (2002). Pleasant surprises: consumer response to unexpected instore coupons, Journal of Marketing Research, 39, 242-52. http://dx.doi.org/10.1509/jmkr.39.2.242.19081

Hirschman, E. (1982). Religious affiliation and consumption processes: an initial paradigm. Research in Marketing.

Hirschman, E. C., \& Holbrook, M. B. (1982). Hedonic consumption: emerging concepts, methods and propositions. Journal of Marketing, 46, 92-101. http://dx.doi.org/10.2307/1251707

Hodge, R. (2004). Factors influencing impulse buying during an online purchase transaction, (unpublished master's thesis), University of Waterloo.

Jones, M. A., Reynolds, K. E., Weun, S., \& Beatty, S. E. (2003). The product-specific nature of impulse buying tendency. Journal of Business Research, 56(7), 505-12. http://dx.doi.org/10.1016/S0148-2963(01)00250-8

Kacen, J. J., \& Lee, J. A. (2002). The influence of culture on consumer impulsive buying behavior. Journal of Consumer Psychology, 12(2), 163-76. http://dx.doi.org/10.1207/S15327663JCP1202_08

Keller, K. (1998). Strategic Brand Management: Building, Measuring, and Managing Brand Equity. Upper Saddle River NJ, Prentice Hall.

Kim, H. (2006). Using Hedonic and Utilitarian Shopping Motivations to Profile Inner City Consumers. Journal of Shopping Center Research, 13(1).

Kotler, P. (2004). Marketing Management: Analysis, Planning, Implementation, and Control. Prentice Hall of India Private Limited, New Delhi.

Lee, Cheng F, Lee, John C, \& Alice, C. (1999). Statistics for Business and Financial Economics. World Scientific Publishing Company, 718. http://dx.doi.org/10.1142/3803

Levy, S. J. (1959). Symbols for sale. Harvard Business Review, 37, 117-19.

Marks, J. (2002). More than a few good men. Home textile today, 23(35).

Morris, B. (1981). Symbolic Consumer Behavior. An Arbour, MI: Association for Consumer Research.

Nisbett, E. R. (2003). The Geography of Thought: How Asians and Westerners Think Differently . . and Why. The Free Press, New York, NY.

Nunnally, J. C. (1978). Psychometric theory (2nd ed.). New York: McGraw-Hill.

Otnes, C., \& McGrath, M. Perceptions and realities of male shopping behavior. Journal of Retailing, 77(1), 111-37. http://dx.doi.org/10.1016/S0022-4359(00)00047-6

Pandey, D. P. (2005). Education in rural marketing. University News, 43, 7-8.

Parker, W. (1997). An empirical typology of perfectionism in academically talented $6^{\text {th }}$ graders. Am, Educat., 34 , 545-562. http://dx.doi.org/10.3102/00028312034003545

Peck, J., \& Wiggins, J. (2006). It Just Feels Good: Customers' Affective Response to Touch and Its Influence on Persuasion. Journal of Marketing, 70, 56-69. http://dx.doi.org/10.1509/jmkg.70.4.56

Piron, F. (1991). A comparaison of emotional reactions experienced by planned, unplanned and impulse purchasers. Advances in Consumer Research, 20, 341-344.

Piron, F. (1991). Defining impulse purchasing. Advances in Consumer Research, 18, 509-14.

Pitt, L., \& Watson, R. (1996). The World Wide Web as an advertising medium: towards an understanding of conversion efficiency. Journal of Advertising Research, 43-54.

Prendergast, P., \& Pitt, L. (1996). Packaging, marketing, logistics and the environment: are there trade-offs?". International Journal of Physical Distribution \& Logistics Management, 6(26), 60-72. http://dx.doi.org/10.1108/09600039610125206

Rettie, R., \& Brewer, C. (2000). The verbal and visual components of package design

Rook, D. (1987). The buying impulse. Journal of Consumer Research, 14, 189-99. http://dx.doi.org/10.1086/209105

Rook, D., \& Fisher, R. (1995). Normative influences on impulsive buying behavior. J Consum., 22, 305-13. http://dx.doi.org/10.1086/209452 
Rook, K. (1987). Social support versus companionship: effect on life stress, loneliness and evaluation by others. Journal of Personality and Social Psychology, 52, 1113-1147. http://dx.doi.org/10.1037/0022-3514.52.6.1132

Sehrawet, M. (2002). Impact of packaging on consumer buying behaviour: a comparative study of rural and urban consumers in Haryana. Unpublished $\mathrm{PhD}$ Thesis.

Sehrawet, M., \& Kundu, S. C. (2003). Packaging as a marketing tool: a study. In M.S. Turan \& S.C. Kundu (Eds.) International Business and Financial Services in WTO Regime (pp. 287-298). Excel Books, New Delhi.

Shaw, M. (1981). Group dynamics: The psychology of small group behavior. New York: McGraw-Hill.

Silayoi, P., \& Speece, M. (2004). Packaging and purchase decisions: An exploratory study on the impact of involvement level and time pressure. British Food Journal, 106(8), 607-628. http://dx.doi.org/10.1108/00070700410553602

Silvera, D. H., Lavack, A. M., \& Kropp, F. (2008). Impulse buying: the role of affect, social influence and subjective wellbeing. Journal of Consumer Marketing, 25(1), 23-33. http://dx.doi.org/10.1108/07363760810845381

Stern, H. (1962). The significance of impulse buying today. Journal of Marketing, 26(2), 59-63. http://dx.doi.org/10.2307/1248439

Tauber, E. M. (1972). Why do people shop? Journal of Marketing, 36, 46-59. http://dx.doi.org/10.2307/1250426

Thomas, J., Cassill, N., \& Forsythe, S. (1991). Underlying dimensions of apparel involvement in consumers' purchase decisions. Clothing and Textile Research Journal, 9(3), 45-8. http://dx.doi.org/10.1177/0887302X9100900307

Unger, L. (1981). Consumer marketing trends in the 1980s: when growth slows. Journal of Consumer Research, 9(2), 69-73.

Van Trijp, H. C. M., Hoyer, W. D., \& Inman, JJ. (1996). Why switch? Product category-level explanations for true variety seeking behavior. Journal of Marketing Research, 38, 281-292. http://dx.doi.org/10.2307/3152125

Verplanken, B., \& Herabadi, A. (2001). Individual differences in impulse buying tendency: feeling and no thinking. European Journal of Personality, 15, 71-83. http://dx.doi.org/10.1002/per.423

Vohs, K. D., \& Faber, R. J. (2007). Spent resources: Self-regulatory resource availability affects impulse buying. Journal of Consumer Researches, 33(4), 537-547. http://dx.doi.org/10.1086/510228

Wakefield, K., \& Baker, J. (1998). Excitement at the mall: Determinants and effects on shopping response. Journal of Retailing, 74(4), 515-539. http://dx.doi.org/10.1016/S0022-4359(99)80106-7

Walle, A. H. (1997). Global behaviour, unique responses: consumption within cultural frameworks. Management Decision, 35(10), 700-8. http://dx.doi.org/10.1108/00251749710192011

Wansink, B. (1994). Advertising's impactct on category substitution. Journal of marketing research, 31, 505-15. http://dx.doi.org/10.2307/3151879

Weinberg, P., \& Gottwald, W. (1982). Impulse consumer buying as a result of emotions. Journal of Business Research, 10, 43-57. http://dx.doi.org/10.1016/0148-2963(82)90016-9

Youn, S., \& Faber, R. (2000). Impulse buying: its relation to personality traits and cues. Advances in Consumer Research, 27, 179-85. 